\title{
Media Pembelajaran Berbasis Video Konten Youtube pada Mata Kuliah Sejarah Musik Materi Musik Kuno
}

\author{
Aldhila Mifta Firdhani \\ Prodi Pendidikan Musik, Fakultas Bahasa dan Seni, Universitas Negeri \\ Jakarta, Jl Rawamangun Muka Jakarta Timur, DKI Jakarta, Indonesia \\ aldhifirdhani@unj.ac.id
}

\begin{abstract}
Abstrak
Tujuan penelitian dan pengembangan ini adalah untuk (1) menghasilkan pengembangan media pembelajaran berbasis video content youtube mata kuliah Sejarah Musik materi sejarah musik kuno, (2) menguji kelayakan media pembelajaran berbasis video content youtube mata kuliah Sejarah Musik materi sejarah musik kuno, dan (3) mengetahui peningkatan minat belajar mahasiswa setelah menggunakan media pembelajara ini sebagai sumber informasi tambahan mahasiswa program studi pendidikan musik untuk memahami sejarah musik kuno. Tahapan penelitian dan pengembangan ini meliputi analisis kebutuhan, perencanaan, pengembangan, dan uji coba pemakaian. Penilaian dan uji kelayakan produk pada uji alfa ini melibatkan 2 (satu) orang ahli media. Uji coba produk (uji beta) melibatkan 32 mahasiswa sebagai subjek uji coba. Data dalam penelitian dan pengembangan ini dikumpulkan melalui angket dan tes minat belajar. Teknik analisis data yang digunakan adalah teknik kualitatif deskriptif, kuantitatif deskriptif, dan uji beda. Hasil penelitian dan pengembangan menunjukkan bahwa: (1) kelayakan media pembelajaran berbasis video content youtube berdasarkan penilaian ahli media mencapai skor 5,64 dengan kriteria "Sangat Baik"; (2) penilaian produk oleh 2 (dua) orang dosen pada uji alfa memiliki skor rata-rata sebesar 4,78 dengan kriteria "Sangat Baik"; (3) peningkatan minat belajar mahasiswa sebesar 4,89. Nilai signifikansi sebesar 0,000 yang menunjukkan bahwa terdapat perbedaan yang signifikan antara nilai rata-rata pada pretest dan posttest. Sehingga dalam hal ini, penggunaan media pembelajaran berbasis video content youtube dapat meningkatkan minat belajr mahasiswa pada mata kuliah sejarah musik.
\end{abstract}

Kata Kunci: Pengembangan Media Pembelajaran Sejarah Musik, Konten Video, Minat Belajar

\begin{abstract}
Research and development aims to: (1) develop learning media based on videos youtube content in music history course ancient music material, (2) test the feasibility of learning media based on videos content in music history course ancient music material, and (3) indicators of increasing interest. Research step includes needs analysis, planning, development, and testing usage. The assessment and product feasibility test in this alpha test involves 2 (one) media experts. The product trial (beta test) involved 32 students as test subjects. Data collected through questionnaires and interest in learning tests. The data analysis technique used is descriptive qualitative technique, quantitative descriptive, and different test. The results show that: (1) the feasibility of learning media based on on expert criteria achieves a score of 5.64 are "Very Good"; (2) product assessment by 2 (two) lecturers in the alpha test had an average score of 4.78 are "Very Good"; (3) student interest in learning by 4.89. A significance value of 0.000 which indicates that there is a significant difference between the mean scores at the pretest and posttest. So in this case, the use of video content-based learning media can increase students interest in learning in the music history course.
\end{abstract}

Keywords: Learning Media Development on Music History, Content Video, Student Interest 


\section{PENDAHULUAN}

Peran teknologi di era revolusi industri 4.0 dalam dunia pendidikan pada saat ini sangat besar. Mudahnya mendapatkan informasi melalui teknologi seolah-olah membuat dunia tanpa batas karena dalam mengakses segala macam sumber informasi saat ini dapat dilakukan dalam genggaman tangan saja. Sejalan dengan apa yang dikatakan oleh Menteri Kemendikbud, Nadiem Makarim yang disiarkan oleh CNBC Indonesia pada 24 oktober 2019, yang mengatakan bahwa peran teknologi dalam dunia pendidikan akan semakin besar untuk menciptakan kualitas efisiensi dan sistem administrasi pendidikan di Indonesia.

Pengaruh perkembangan teknologi informasi yang semakin pesat tentu tidak dapat dihindari dalam dunia pendidikan. Haris Budiman (2017: p.76) mengatakan bahwa tuntutan global menuntut dunia pendidikan untuk selalu dan senantiasa menyesuaikan perkembangan teknologi terhadap usaha dalam peningkatan mutu pendidikan, khususnya penyesuaian dalam proses pembelajaran. Lebih lanjut adanya perubahan hal tersebut tentu memicu pergeseran dalam dunia pendidikan yaitu dari pertemuan tatap muka yang konvensional ke arah yang lebih terbuka. Hal ini tentu akan membuat pendidikan lebih luwes (fleksibel), terbuka dan dapat diakses oleh siapapun yang memerlukan (Kusnayat et al., 2020: p.163). Tentunya hal ini akan membuat pendidikan di masa mendatang akan lebih ditentukan oleh jaringan informasi yang memungkinkan berinteraksi dan berkolaborasi.

Peran media pembelajaran dapat dimanfaatkan baik oleh pendidik maupun peserta didik dalam meningkatkan kualitas, produktivitas, efektifitas, dan akses pendidikan. Lebih lanjut Simanjuntak (2013: p.8) menegaskan bahwa teknologi informasi dan komunikasi memiliki manfaat yang besar dalam pendidikan yang diantaranya adalah: (1) sebagai gudang ilmu pengetahuan, (2) sebagai fasilitas pembelajaran, (3) sebagai infrastruktur pembelajaran, dan (4) sebagai alat bantu pembelajaran. Lebih lanjut Handayani et al., (2019: p.1) menambahkan bahwa dalam dunia pendidikan ini, teknologi informasi dan komunikasi memiliki peran penting dalam kecanggihan berkomunikasi guna memberikan kelancaran dalam proses pembelajaran. Dalam hal ini teknologi informasi dan komunikasi dapat digunakan sebagai media pembelajaran dan media komunikasi antara pendidik dan peserta didik.

Adanya pemanfaatan teknologi informasi dan komunikasi dalam dunia pendidikan ini tentu akan membantu proses pembelajaran karena menciptakan suatu interaksi antara pendidik dan peserta didik, sehingga mampu memaksimalkan tujuan pembelajaran. Implementasi teknologi, informasi, dan komunikasi dalam pembelajaran dapat memperluas akses terhadap pembelajaran, membantu memvisualisasikan ide-ide abstrak, mempermudah pemahaman materi, dan menampilkan materi pembelajaran yang lebih menarik. Sejalan dengan pernyataan Rifa'i, (2018: p.27-28) bahwa sesuai dengan paradigma belajar abad 21, pendidikan harus dibangun dengan lebih mengedepankan integrasi antara pengetahuan, keterampilan, dan sikap, serta harus menitikberatkan pada kualitas pengembangan dan penguasaan teknologi pembelajaran.

Adanya proses pembelajaran yang uptodate pada saat ini yang tidak dapat terlepas dari perkembangan teknologi tentu perlu diseimbangkan dengan kemampuan pendidik, dimana saat ini bukan merupakan sumber satu-satunya dalam menyampaikan informasi. Yana \& Adam, (2019: p.3) menyebutkan bahwa untuk memberikan pelayanan kepada generasi yang terlahir sebagai "digital native", dimana penggunaan teknologi adalah salah satu ciri khas dari mereka perlu diperhatikan secara seksama. Pendidik dituntut perlu memahami dan menguasai perkembangan teknologi, informasi, dan komunikasi untuk dimanfaatkan dalam dunia pendidikan. Pendidik perlu menyesuaikan diri terhadap perkembangan tersebut. Lebih lanjut dengan adanya penguasaan-penguasaan tersebut, diharapkan dapat membantu pendidik dalam menyajikan bahan pembelajaran dengan baik. Pendidik akan lebih mudah menyampaikan materi kepada peserta didik dengan mudah dan menarik, sehingga sekaligus juga dapat membangkitkan motivasi belajar peserta didik (Teni Nurita, 2018: p.173). 
Adapun teknologi informasi dan komunikasi pada saat ini yang sedang digemari oleh masyarakat untuk mendapatkan informasi (media pembelajaran) adalah melalui tayangan Video YouTube. YouTube merupakan sebuah situs website yang digunakan untuk sharing video secara online. Pengguna YouTube saat ini tersebar disegala penjuru dunia dari berbagai kalangan usia, mulai dari anak-anak hingga orang dewasa. Bagi pengguna YouTube, mereka dapat mengupload video, search video, menonton video, dan diskusi Tanya jawab secara gratis. Oleh sebab dapat dikatakan bahwa YouTube berpotensi untuk dimanfaatkan sebagai media pembelajaran.

Sejalan dengan pernyataan sebelumnya, peran pemanfaatan konten YouTube sebagai media pembelajaran telah dibuktikan berdasarkan hasil penelitian yang dilakukan oleh Rasagama, (2020: p.100) yang menyatakan bahwa media pembelajaran berbasis video youtube dapat meningkatkan kemampuan pemahaman konsep materi yang sedang dipelajari, sesuai dengan tujuan pembelajaran yang ingin dicapai dalam pembelajaran tersebut.

Pentingnya memanfaatkan YouTube sebagai media pembelajaran (media informasi) bertolak belakang pada rumpun ilmu musik khususnya sejarah musik. Sumber informasi terkait sejarah musik di Youtube terutama pada materi perkembangan musik kuno yang menggunakan Bahasa Indonesia saat ini masih sangat kurang. Hal tersebut dibuktikan berdasarkan hasil studi pendahuluan yang dilakukan oleh peneliti. Berdasarkan hasil pencarian di situs youtube, informasi terkait materi perkembangan musik kuno masih belum ada, sebagian besar informasi terkait sejarah musik yang ditemukan dimulai setelah abad pertengahan dan renaisans.

Lebih lanjut, berdasarkan hasil studi pendahuluan yang sudah dilakukan oleh peneliti khususnya terkait proses pembelajaran yang ada dikelas sejarah musik di Program Studi Pendidikan Musik, ditemukan beberapa kendala yang dihadapi oleh peserta didik dalam hal ini adalah mahasiswa. Kendala tersebut diantaranya adalah terkait minat belajar mahasiswa musik sangat kurang terutama dalam hal membaca materi. Sebagian besar peserta didik menganggap belajar lebih mudah dipahami jika media pembelajaran yang digunakan berbentuk audio visual, sehingga mereka semakin tertarik dan kemampuan mereka akan semakin maksimal.

Oleh sebab itu dalam penelitian ini, peneliti ingin mengembangkan media pembelajaran khususnya dalam mata kuliah sejarah musik. Pengembangan akan dilakukan melalui pembuatan beberapa video content terkait sejarah perkembangan musik kuno yang nantinya akan diupload di youtube, sehingga dapat dimanfaatkan oleh masyarakat khususnya calon pendidik musik (mahasiswa) di program studi pendidikan musik UNJ sebagai media untuk memperoleh informasi sebagai sumber belajar secara mandiri.

\section{METODE PENELITIAN}

Penelitian ini menggunakan metode penelitian pengembangan dengan menggunakan model Borg \& Gall. Langkah-langkah penelitian dan pengembangan yang digunakan meliputi: (1) studi pendahuluan dan pengumpulan data, (2) perencanaan, (3) pengembangan bentuk produk awal, (4) tahap awal pengujian lapangan, (5) revisi produk utama, (6) pengujian hasil produk utama. 


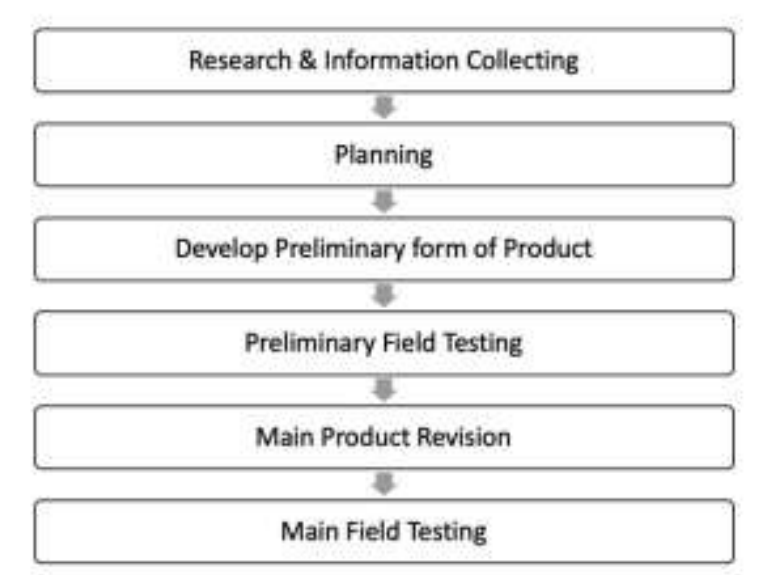

Gambar 1. Desain Model Pengembangan Borg \& Gall

Pada penelitian ini, model pengembangan Borg \& Gall digunakan untuk menghasilkan suatu produk media pembelajaran berupa video content Youtube. Pengembangan dilakukan sesuai dengan tahapan demi tahapan yang diuraikan oleh Borg \& Gall. Adapun materi konten video adalah mata kuliah sejarah musik dengan materi pokok perkembangan musik kuno.

Pada tahap penelitian dan pengumpulan data, langkah yang dilakukan adalah melalui studi literatur yang memuat teori-teori atau konsep terkait dengan masalah yang akan diteliti. Hasil dari studi literatur ini kemudian dijadikan sebagai pendukung dalam tahap penelitian selanjutnya. Selain studi literatur, observasi dan wawancara juga dilakukan dalam penelitian ini, diantaranya adalah untuk melihat kondisi pembelajaran di dalam kelas. Setelah itu, langkah yang dilakukan adalah dengan menyiapkan kesimpulan dari hasil studi literatur dan observasi di dalam kelas.

Pada tahap perencanaan, langkah-langkah penelitian yang dilakukan adalah dengan menetapkan rancangan media, merumuskan tujuan pengembangan, mengidentifikasi kegiatan yang dilaksanakan saat penelitian, dan pengujian rancangan media dalam skala kecil. Dalam perumusan tujuan terkait apa yang akan dipelajari dan dicapai oleh mahasiswa, diperlukan fokus pemberian materi yang akan disampaikan, seperti bagaimana karakteristik musik pada masingmasing negara, latar belakang budaya bangsa tersebut, serta keunikan pengembangan unsur-unsur musik yang ada pada bangsa tersebut seperti penggunaan tangganada arab dengan maqam sedangkan india dengan istilah struti.

Pada tahap pengembangan bentuk produk awal, pengembangan draf produk merupakan langkah pengembangan produk awal yang dihasilkan. Adapun langkah yang dilakukan dalam tahap ini adalah persiapan komponen pendukung, menyiapkan buku pedoman dan buku petunjuk, dan evaluasi terhadap alat-alat pendukung. Pengembangan draf ini adalah sebagai gambaran produk yang masih mentah dengan menyiapkan komponen-komponen pendukung dalam pembuatannya. Adapun langkah dapat diuraikan sebagai berikut (1) pembuatan awal desain produk, dan (2) validasi media pembelajaran.

Pada tahap awal pengujian lapangan, uji coba awal atau uji kelompok kecil dilakukan terhadap penggunaan media pembelajaran yang sudah dihasilkan dan sudah divalidasi. Langkah uji coba kelompok kecil dilakukan dengan melalui proses pembelajaran dengan memanfaatkan media pembelajaran berbasi video content YouTube mata kuliah sejarah musik dengan materi perkembangan musik kuno. Dalam hal ini, uji yang dilakukan adalah Uji Alfa. Uji ini dilakukan untuk direview oleh ahli media dan materi, guna mengetahui kelebihan dan kekurangan yang ada pada media yang sedang dibuat. Berdasarkan hasil uji alfa ini kemudian digunakan untuk mengetahui terkait kelayakan produk media pembelajarannya dengan cara diuji coba. Hasil dari uji alfa ini yang disertai dengan komentar dan masukan dari para ahli kemudian dijadikan bahan pertimbangan tim pengembang media untuk memperbaiki media agar lebih baik lagi. 
Pada tahap revisi produk utama, pengembang melakukan revisi berdasarkan hasil uji coba skala kecil diantaranya adalah: (1) perbaikan atas dasar tingkat efektivitas produk yang telah diterapkan pada kelompok kecil, (2) perbaikan atas dasar kritik, masukan, dan saran oleh pendidik sebagai pengguna dalam tingkat keberhasilan produk, dan (3) perbaikan atas dasar skor kelayakan produk yang dinilai oleh pendidik sebagai pengguna.

Pada tahap pengujian hasil produk utama, dilakukan uji coba lapangan atau uji kelompok besar. Uji kelompok besar ini memiliki tujuan yaitu untuk menilai tingkat keberhasilan dan efektivitas produk yang diperoleh dari hasil nilai pretest dan posttest. Adapun tahapan dan desain uji coba produk dapat dilihat pada gambar 2 .

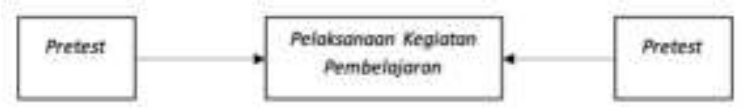

Gambar 2. Desain Uji Coba Produk

Dalam tahapan desain uji coba produk ini dapat diuraikan sebagai berikut: (1) pada tahap pretest ini, penilaian dilakukan sebelum kegiatan pembelajaran yang memanfaatkan media pembelajaran berbasis video content youtube dalam mata kuliah sejarah musik 1 berlangsung. Bentuk tes yang digunakan dalam pretest ini adalah pilihan ganda. (2) pada tahap pemberian perlakuan, proses pelaksanaan pembelajaran yang memanfaatkan media pembelajaran berbasis video content youtube dalam mata kuliah sejarah musik 1. Proses pembelajaran di desain agar dapat memaksimalkan penggunaan media pembelajaran yang sudah dibuat oleh peneliti, dan (3) pada tahap posttest ini, penilaian dilakukan setelah kegiatan pembelajaran yang memanfaatkan media pembelajaran berbasis video content youtube dalam mata kuliah sejarah musik 1 berlangsung. Bentuk tes yang digunakan dalam pretest ini adalah pilihan ganda.

Teknik pengumpulan data dilakukan melalui dokumentasi, observasi, penyebaran kuisioner atau angket dan tes. Angket dalam penelitian ini digunakan untuk mengetahui kelebihan dan kekurangan dari produk yang sedang dikembangkan, serta memberikan penilaian kepada produk tersebut. Dalam penelitian dan pengembangan ini terdapat 4 (empat) jenis angket yang digunakan yaitu: (1) angket untuk ahli media, (2) angket untuk guru, dan (3) angket siswa. Sedangkan tes dalam penelitian ini digunakan untuk mengukur minat belajar awal yang dimiliki oleh mahasiswa (pretest) dan mengukur minat belajar akhir yang dimiliki oleh mahasiswa (posttest).

Teknik analisis data dalam penelitian ini dilakukan pada saat uji validasi ahli dan uji validasi pengguna. Pengukuran hasil angket dilakukan menggunakan skala likert. Skala likert dilakukan untuk mengukur sikap, pendapat, dan persepsi seseorang tentang fenomena social.

Tabel 1. Tabel Skala Likert (Sumber: Sugiyono, 2014: p.216)

\begin{tabular}{cl}
\hline Skor & \multicolumn{1}{c}{ Kategori } \\
\hline $\mathbf{1}$ & Sangat tidak baik \\
\hline $\mathbf{2}$ & Kurang baik \\
\hline $\mathbf{3}$ & Cukup baik \\
\hline $\mathbf{4}$ & Baik \\
\hline $\mathbf{5}$ & Sangat baik \\
\hline
\end{tabular}

Teknik analisis data selanjutnya adalah dengan mengetahui prosentasi validasi ahli, validasi Bahasa, dan validasi desain media yang dilakukan dengan menggunakan rumus: 


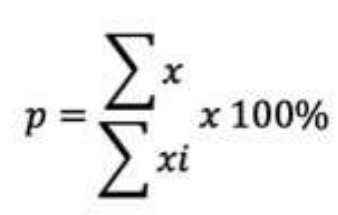

Gambar 3. Rumus Prosentase Hasil Validasi (Sumber: Arikunto, 2007: p.216)

Setelah mendapatkan hasil analisis data yang diperoleh, langkah berikutnya adalah dengan mengubah prosentase penilaian menjadi data kualitatif deskriptif. Kualitas kelayakan produk media pembelajaran ini dapat dilihat dari kriteria kelayakan hasil validasi yang digambarkan pada tabel

Tabel 2. Kualifikasi Kelayakan Produk (Sumber: Arikunto, 2007: p.216)

\begin{tabular}{ccc}
\hline $\begin{array}{c}\text { Tingkat } \\
\text { Pencapaian }\end{array}$ & Kualifikasi & Keterangan \\
\hline $\mathbf{8 5 \%}-\mathbf{1 0 0 \%}$ & Sangat Baik & $\begin{array}{c}\text { Tidak Perlu } \\
\text { Revisi }\end{array}$ \\
\hline $\mathbf{7 5 \%}-\mathbf{8 4 \%}$ & Baik & $\begin{array}{c}\text { Tidak Perlu } \\
\text { Revisi }\end{array}$ \\
\hline $\mathbf{6 5 \%}-\mathbf{7 4 \%}$ & Cukup & Perlu Revisi \\
\hline $\mathbf{5 5 \% - 6 4 \%}$ & Kurang & Perlu Revisi \\
\hline $\mathbf{0 \% - 5 4 \%}$ & Kurang Sekali & Perlu Revisi \\
\hline
\end{tabular}

Adapun data minat belajar mahasiswa yang berupa nilai angka baik dalam tahapan pretest maupun posttest, digunakan untuk mengetahui adanya perbedaan yang signifikan antara minat belajar pretest dan posttest yang dilakukan dengan menggunakan Uji T. Pengambilan keputusan didasarkan pada perolehan signifikansi berdasarkan hasil analisis. Jika nila $<0,05$ maka dapat disimpulkan terdapat perbedaan yang signifikan antara hasil nilai pretest maupun posttest, sebaliknya jika nilai signifikansinya > 0,05 dapat disimpulkan bahwa data tidak ada perbedaan yang signifikan jelas. Adapun sebelum melakukan pengujian tersebut, dilakukan terlebih dahulu uji prasyarat analisis yaitu meliputi uji normalitas dan uji homogenitas data yang dilakukan dengan bantuan perangkat lunak IBM SPSS Seri 23.

\section{HASIL DAN PEMBAHASAN}

Penelitian dan pengembangan ini dilakuakan melalui 5 (lima) tahapan yaitu: 1) analisis kebutuhan, 2) perencanaan, 3) perancangan, 4) pengembangan, dan 5) uji coba pemakaian. Adapun hasil yang didapatkan dari tahapan tersebut dapat diuraikan sebagai berikut:

\section{Hasil Tahap Analisis Kebutuhan}

Pada tahap ini, analisis kebutuhan dilakukan pada bulan April sampai dengan Juni 2020. Tahapan ini dilakukan dalam bentuk studi literatur dan studi lapangan. Adapun hasil yang didapatkan diantaranya adalah sebagai berikut:

\section{Hasil Studi Lapangan}

Studi lapangan dilakukan untuk mengetahui kondisi pembelajaran sejarah musik baik ketika pelaksanaan ofline maupun secara daring (online). Adapun hasil observasi yang 
sudah dilakukan dapat diketahui bahwa sumber belajar sejarah musik masih sangat minim termasuk media pembelajaran yang digunakan. Ditengah kondisi pandemic yang saat ini masih terjadi masih memerlukan sumber atau media pendukung agar mahasiswa lebih mudah memahami materi yang diberikan.

\section{Hasil Angket}

Pemberian angket dalam penelitian dan pengembangan ini dilakukan oleh pengembang media melalui penggunaan Google Form. Berdasarkan hasil pengisian angket yang diberikan kepada mahasiswa, dapat diketahui bahwa sebagian besar mahasiswa memiliki minat belajar yang masih kurang, terutama jika diberikan materi yang bersifat membaca buku teks. Sebagian besar dari mereka juga menganggap bahwa materi lebih mudah dipahami ketika disampaikan secara verbal. Sehingga dari pernyataan-pernyataan tersebut dapat dikatakan bahwa perlu adanya sebuah inovasi untuk mengembangkan proses pembelajaran. Adapun inovasi tersebut diantaranya adalah diharapkan dapat berupa video pembelajaran.

\section{Studi Pustaka}

Studi Pustaka dalam penelitian dan pengembangan ini dilakukan untuk menggali lebih mendalam terkait informasi yang dibutuhkan dalam prosess mengembangkan produk berupa video pembelajaran. Adapun studi Pustaka ini dilakukan dengan menganalisis bukubuku sumber teks baik yang berasal dari Indonesia maupun luar Indonesia. Berdasarkan hasil studi Pustaka, kemudian dapat ditentukan beberapa sub pokok bahasan yang dikembangkan dalam penelitian dan pengembangan ini diantaranya adalah sebagai berikut: 1) musik mesir, 2) musik romawi, 3) musik Yunani, 4) musik arab, 5) musik india, 6) musik china, 7) musik jepang, dan 8) musik Indonesia.

\section{Hasil Tahap Perencanaan}

Pada tahap perencanaan ini terdiri dari definisi ruang lingkup, identifikasi karakteristik mahasiswa, dan pembuatan dokumen perencanaan. Adapun hasil dari tahap ini adalah:

\section{Definisi Ruang Linkup}

Pada tahapan ini perumusan tujuan sangat menentukan arah pengembangan media pembelajaran. Beberapa aspek tujuan yang perlu diganli berdasarkan hasil analisis kebutuhan dan menentukan ruang lingkup Batasan materi yang kemudian dituangakan dalam pembuatan produk. Berikut hasil perencanaan materi dalam produk dapat dilihat pada tabel 1 .

Tabel 3. Hasil Perencanaan Materi dalam Produk

\begin{tabular}{ll}
\hline $\begin{array}{c}\text { Materi } \\
\text { Pokok }\end{array}$ & \multicolumn{1}{c}{ Deskripsi Materi } \\
\hline Musik & Video ini berisi terkait perkembangan \\
Mesir & atau sejarah musik mesir jaman kuno. \\
Kuno & Selain latar belakang histori, juga \\
& terdapat aspek sosial yang ada pada \\
& bangsa tersebut yang mempengaruhi \\
& perkembangan musik, karakteristi, \\
& struktur musik, serta perkembangan \\
& unsur-unsur musik seperti adanya
\end{tabular}


tetracord, perkembangan alat musik harpa serta alat musik lainnya. Selain itu peran penting dari seorang filsuf Plato terkait musik juga dijelaskan pada materi ini.

Musik Video ini berisi terkait perkembangan Yunani atau sejarah musik Yunani jaman Kuno kuno. Selain latar belakang histori, juga terdapat aspek sosial yang ada pada bangsa tersebut yang mempengaruhi perkembangan musik, karakteristi, struktur musik, serta perkembangan unsur-unsur musik. Dalam perkembangan musik Yunani ini difokuskan pada 2 tahap perkembangan yaitu (1) tahap perkembangan musik kenizah, dan (2) perkembangan musik synagogal.

Musik Video ini berisi terkait perkembangan Yahudi atau sejarah musik Yahudi jaman Kuno kuno. Selain latar belakang histori, juga terdapat aspek sosial yang ada pada bangsa tersebut yang mempengaruhi perkembangan musik, karakteristi, struktur, serta perkembangan unsur-unsur musik. Adapun fokus materinya dibagi kedalam 3 tahap perkembangan yaitu: (1) perkembangan musik masa mitis, (2) perkembangan musik saat hijrahnya suku doris, dan (3) perkembangan musik masa klasik dan helenisme. Selain itu, pada materi ini juga dijelaskan terkait estetikaestetika musik yang dinyatakan oleh beberapa filsuf seperti Plato, Aristoteles, dan Aristoxenos.

Musik Video ini berisi terkait perkembangan Roma atau sejarah musik roma jaman kuno. Kuno Selain latar belakang histori, juga terdapat aspek sosial yang ada pada bangsa tersebut yang mempengaruhi perkembangan musik, karakteristi, struktur musik, serta perkembangan unsur-unsur musik. Pada materi pokok ini, materi difokuskan pada hubungan pentingnya semangat bangsa tersebut terhadap perkembangan musiknya. Lebih lanjut materi alat musik difokuskan pada informasi terkait alat musik orgel-hidraulis, khitara, dan nablion. Sedangkan tokoh yang dijelaskan pada materi ini yang memiliki 
Grenek: Jurnal Seni Musik Vol. 10 No. 1 (Juni 2021) Page: 29-45

Prodi Pendidikan Musik FBS Unimed

p- ISSN 2301-5349

e- ISSN 2579-8200

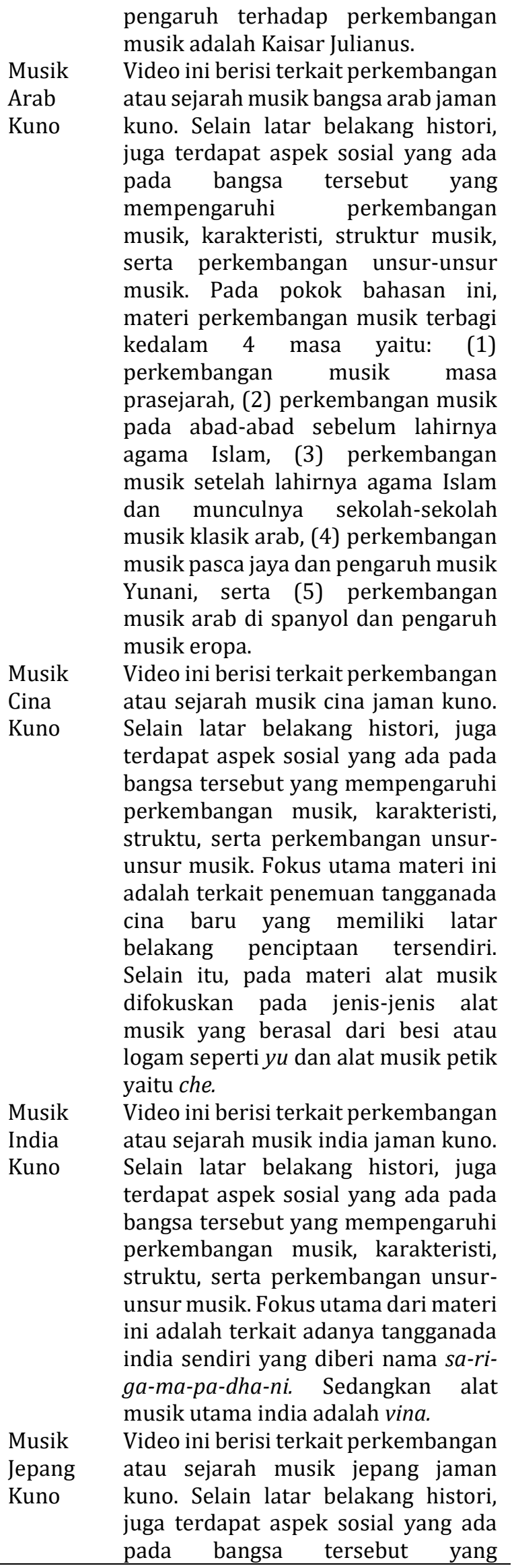




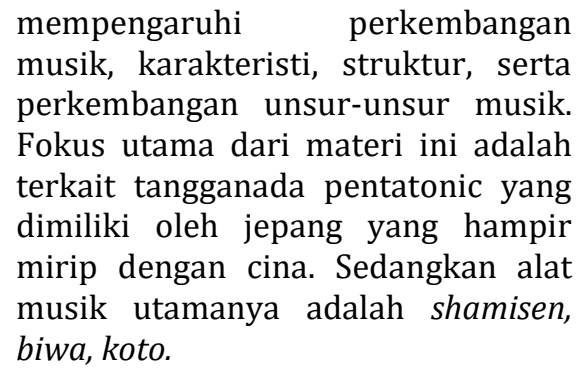

Berdasarkan tabel tersebut dapat diketahui bahwa perencanaan materi difokuskan pada aspek pengetahuan kognitif mahasiswa terkait pemahamannya dalam perkembangan sejarah musik bangsa-bangsa besar di dunia yang memiliki karekteristik dan keunikan sendiri.

\section{Identifikasi Karakteristik Mahasiswa}

Pada tahapan ini, selain memahami konsep materi-materi apa saja yang perlu disampaikan dalam video pengembangan, juga harus memahami setiap-setiap karakteristik mahasiswa yang ada sebagai subjek uji coba. Dalam hal ini, yang perlu dipahami adalah aspek perkembangan diri tingkat dewasa awal.

Berdasarkan hasil pengamatan, diketahui bahwa mahasiswa sebagai subjek yang diteliti memiliki karakteristik adanya dorongan selalu bereksperimen dan bereksplorasi. Dalam hal ini adalah ingin menguatkan jati diri yang dimilikinya. Dalam segi proses pembelajaran, subjek berpendapat bahwa pembelajaran secara audio visual lebih mudah dibandingkan secara visual saja. Dalam hal ini tentu menguatkan pentingnya penelitian dan pengembangan ini.

\section{Pembuatan Dokumen Perencanaan}

Pada tahap pembuatan dokumen perencanaan ini berisi tentang rancangan produk awal, seperti skema produk, pengembangan dan analisis materi, pemilihan materi yang akan dijadikan video pembelajaran, serta pembuatan soal evaluasi dan latihan.

\section{Hasil Perancangan}

Pada proses ini, hasil yang didapatkan berupa bentuk skrip yang akan digunakan sebagai panduan dalam proses perekaman video pembelajaran yang akan dibicarakan oleh talent. Adapun dalam pembuatan skrip ini memiliki tujuan yaitu untuk mempermudah proses produksi agar dapat berjalan dengan efektif. Berikut merupakan contoh bentuk hasil pembuatan skrip yang sudah dibuat oleh tim pengembang. 


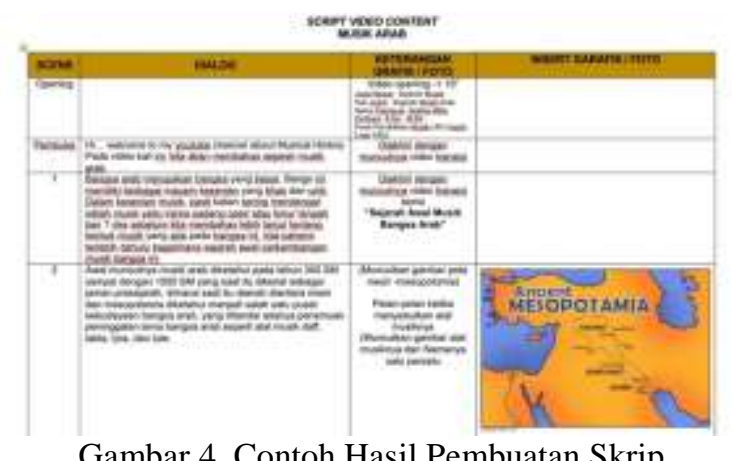

Gambar 4. Contoh Hasil Pembuatan Skrip

Pembuatan skrip ini dilakukan oleh pengembang dan kemudian diberikan kepada narrator, dan tim produksi serta tim editor untuk dilakukan analisis dalam mempersiapkan proses perekaman video.

4. Hasil Pengembangan

Hasil Proses Pembuatan Video Opening

Proses pembuatan video opening ini dilakukan oleh tim pengembang media pembelajaran dengan bantuan beberapa aplikasi pendukung baik aplikasi yang bersifat online maupun ofline. Berikut merupakan contoh bentuk video opening yang sudah dihasilkan.

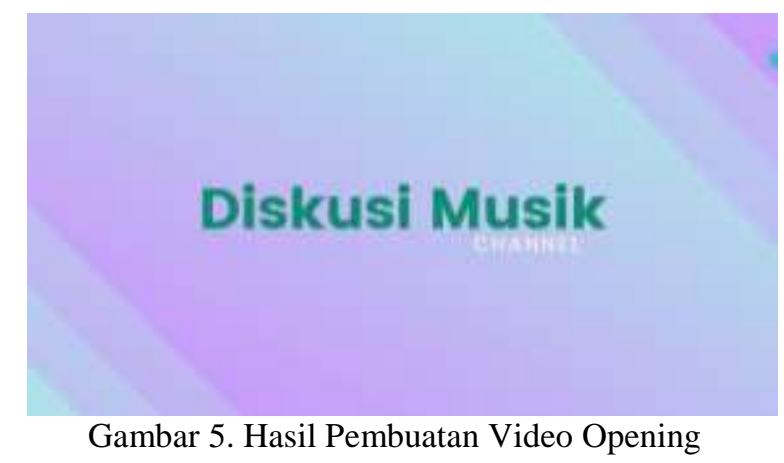

Bentuk video opening ini berupa video grafis yang berisi tentang nama channel yang akan digunakan dalam konten youtube dengan diberi nama "Diskusi Musik Channel". Video grafis tersebut dibuat menggunakan penggabungan dari aplikasi Canva dan Kinemaster Premium.

\section{Hasil Pembuatan Musik Opening}

Proses pembuatan musik opening ini dilakukan oleh pengembang media pembelajaran dengan bantuan aplikasi musik "Garage Band". Berikut merupakan contoh bentuk video opening yang sudah dihasilkan. 


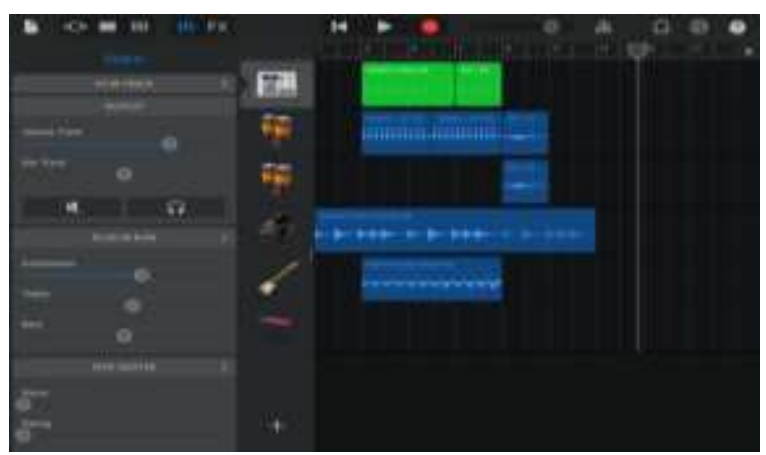

Gambar 6. Proses Pembuatan Musik Opening

Musik opening ini dibuat dengan menggunakan 4 (empat) pilihan instrument musik yaitu synthesizer, cajon, piano, dan gitar. Adapun hasil akhir dari pembuatan musik opening ini adalah berdurasi 12 detik.

\section{Hasil Pembuatan Video Isi Materi Pembelajaran}

Proses pembuatan video isi materi pembelajaran ini dilakukan oleh pengembang media pembelajaran dengan bantuan aplikasi KineMaster Premium. Adapun video ini dibuat dalam 8 (delapan) macam materi, dimana akan dijadikan 8 konten video. Konsep editing video pembelajaran yang dilakukan dalam penelitian dan pengembangan ini dibuat dengan bantuan penggunaan green screen, sehingga dalam proses editingnya background video dapat diubah sesuai dengan keinginan. Berikut merupakan proses awal editing video pembelajaran.

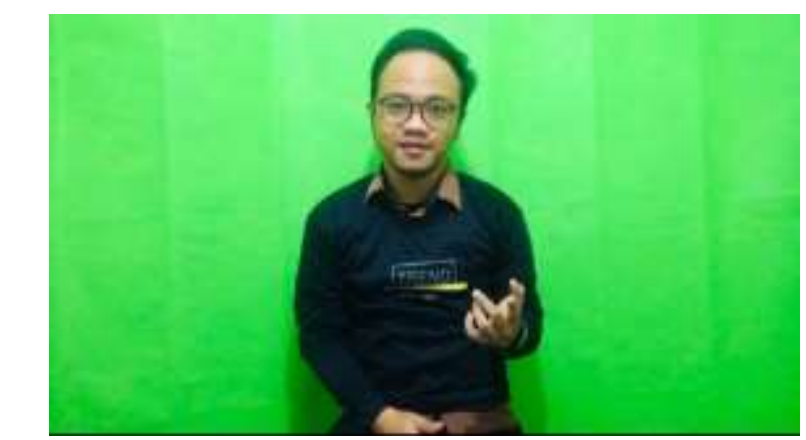

Gambar 7. Proses Pembuatan Video Sebelum Editing Backsound

Setelah proses perekaman video dilakukan, langkah berikutnya adalah dengan mengatur pengaturan background sehingga gambar lebih terlihat jelas dan apik. Selain itu proses editing audio juga dilakukan dalam proses ini. Berikut merupakan contoh proses editing background dalam penelitian ini. 


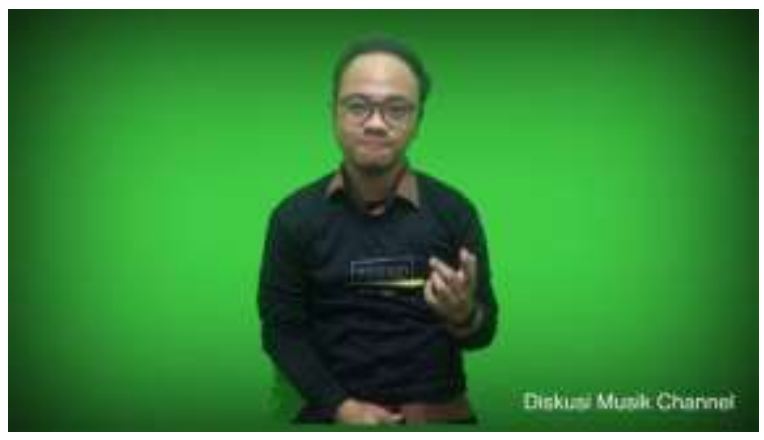

Proses terakhir yang dilakukan setelah editing background dan suara audio vokal, proses selanjutnya yang dilakukan adalah proses memasukkan musik backsound kedalam video utama, dalam tahap ini sangat diperlukan konsentrasi agar suara vokal tidak tertutup oleh suara backsound musik. Adapun secara keseluruhan pada masing-masing konten yang dibuat akan melalui proses seperti yang diungkapkan tersebut. Sehingga secara keseluruhan terbentuklah 8 (delapan) video konten perkembangan musik kuno.

\section{Hasil Uji Coba} Hasil Uji Alfa

Uji alfa yang dilakukan dalam penelitian dan pengembangan media pembelajaran ini dilakukan untuk memperoleh penilaian dan mengetahui kelebihan serta kekuarang dari produk media pembelajaran yang sedang dikembangkan. Uji alfa ini dilakukan oleh 2 (dua) orang ahli media dengan memberikan review dan penilaian sesuai dengan bidang keahliannya masing-masing. Dalam penelitian dan pengembangan ini, uji alfa oleh ahli media dilakukan oleh Afrizal Yudha Septiawan, M.Pd. (dosen Pendidikan musik UNILA, yang memiliki latar belakang pernah membuat produk multimedia pengembangan media pembelajaran). Terdapat 2 (dua) poin pokok dalam penilaian media pembelajaran ini, yaitu aspek tampilan media pembelajaran dan kualitas penyajian media pembelajaran. Adapun hasi yang diberikan menyatakan bahwa media yang sudah dibuat sudah baik dengan skor rata-rata sebesar 4,78. Hasil penialaian ini juga menunjukan mahwa media yang sedang dikembangkan ini sudah laya digunakan dalam proses pembelajaran.

\section{Hasil Uji Beta}

Uji beta yang dilakukan dalam penelitian dan pengembangan media pembelajaran ini dilakukan pada jumlah subjek yang lebih besar. Adapun subjek yang terlibat dalam penelitian ini adalah mahasiswa yang mengambil mata kuliah sejarah musik 1 dengan jumlah 32 mahasiswa. Adapun hasul analisis yang dilakukan memperoleh skor rata-rata sebesar 4, 89. Berdasarkan tabel konversi data kuantitatif ke data kualitatif dengan skala 5 skor yang diperoleh tersebut termasuk dalam kriteria "Sangat Baik".

\section{Hasil Uji T}

Uji $\mathrm{T}$ yang dilakukan dalam penelitian dan pengembangan media pembelajaran ini dilakukan untuk mengetahui adakah perbedaan yang cukup signifikan antara mahasiswa yang belum melihat video pembelajaran dengan yang sudah melihat video pembelajaran yang sedang dikembangkan ini. Adapun untuk mengetahui uji T ini, perlu dilakukan terlebih dahulu uji prasyarat analisis, yang diantaranya adalah uji normalitas dan uji homogenitas data. Dalam pengujian ini, data diolah menggunakan bantuan perangkat lunak SPSS Seri 23. a. Hasil Uji Normalitas Data Pretest dan Posttest 
Uji normalitas dilakukan pada kelompok eksperimen yang diberikan sebuah treatment dan kelompok kontrol yang tidak diberikan sebuah treatment. Uji normalitas dilakukan untuk mengetahui apakah data mempunyai sebaran yang berdistribusi normal atau tidak. Uji normalitas yang digunakan dalam penelitian ini adalah uji normalitas Saphiro-Wilk. Uji normalitas Saphiro-Wilk dilakukan dengan menggunakan bantuan software SPSS 23. Untuk mengetahui data berdistribusi normal digunakan kriteria keputusan. Johnson dan Wichern, (2007) menyatakan bahwa data berdistribusi normal apabila nilai signifikansi $>0,05$. Berikut merupakan hasil uji normalitas data pretest kelompok eksperimen.

Tabel 2. Hasil Uji Normalitas Data Pretest Kelompok Eksperimen

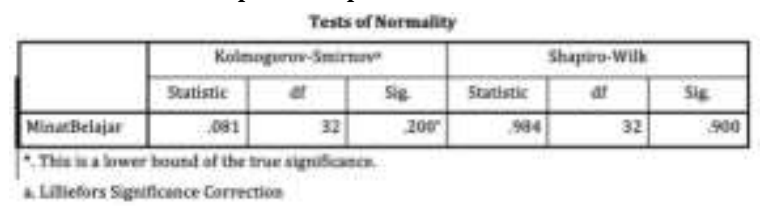

Berdasarkan data tersebut dapat diketahui bahwa hasil uji normalitas pada pada kelompok eksperimen saat pretest nilai signifikansinya adalah 0.900 . Berdasarkan hasil tersebut dapat dikatakan bahwa nilai $>0,05$, sehingga data dapat dikatakan berdistribusi normal. Adapun hasil uji normalitas dengan menggunakan uji normalitas Saphiro-Wilk pada kelompok kontrol saat pretest dapat dilihat pada tabel berikut.

Tabel 3. Hasil Uji Normalitas Data Pretest Kelompok Kontrol

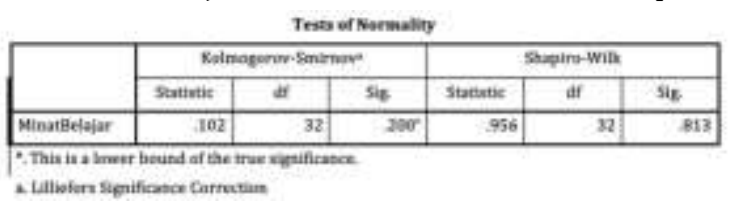

Berdasarkan data tersebut dapat diketahui bahwa hasil uji normalitas pada kelompok kontrol saat pretest nilai signifikansinya adalah 0.813 . Berdasarkan hasil tersebut dapat dikatakan bahwa nilai $>0,05$, sehingga data dapat dikatakan berdistribusi normal. Lebih lanjut uji normalitas juga dilakukan pada saat posttest. Uji normalitas dilakukan dengan menggunakan uji normalitas Saphiro-Wilk pada kelompok eksperimen saat posttest dapat dilihat pada tabel berikut.

Tabel 4. Hasil Uji Normalitas Data Posttest Kelompok Eksperimen

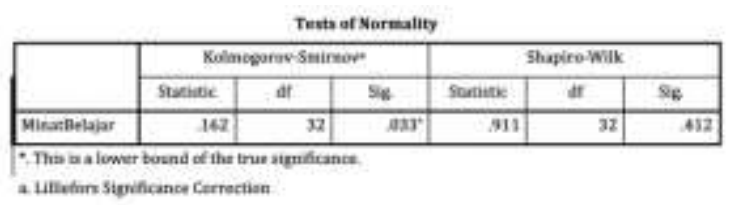

Berdasarkan data tersebut dapat diketahui bahwa hasil uji normalitas pada kelompok eksperimen saat pretest nilai signifikansinya adalah 0.412 . Berdasarkan hasil tersebut dapat dikatakan bahwa nilai $>0,05$, sehingga data dapat dikatakan berdistribusi normal. Berikutnya uji normalitas dilakukan pada saat posttest. Uji normalitas dilakukan dengan 
menggunakan uji normalitas Saphiro-Wilk pada kelompok kontrol saat posttest dapat dilihat pada tabel berikut.

Tabel 5. Hasil Uji Normalitas Data Posttest Kelompok Kontrol

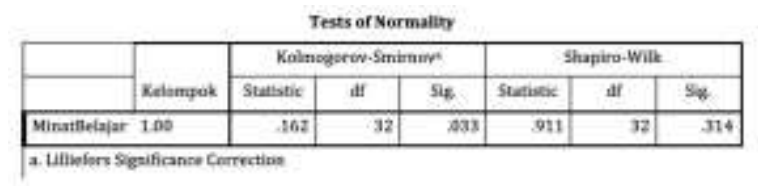

Berdasarkan tabel tersebut dapat diketahui bahwa hasil uji normalitas kelompok kontrol saat posttest nilai signifikansinya adalah 0.314 . Berdasarkan hasil tersebut dapat dikatakan bahwa nilai > 0,05, sehingga data dapat dikatakan berdistribusi normal.

\section{b. Hasil Uji Homogenitas Data Pretest dan Posttest}

Uji homogenitas dilakukan pada kelompok eksperimen yang diberikan sebuah treatment dan kelompok kontrol yang tidak diberikan sebuah treatment. Pengujian kesamaan varians data kelompok eksperimen maupun kelompok kontrol pada saat pretest dan posttest dilakukan menggunakan uji homogentitas. Adapun hasil uji homogenitas multivariat menggunakan uji Levene's dengan melihat nilai signifikansi dari tabel Levene's test pada kelompok eksperimen dan kelompok kontrol saat pretest dapat dilihat pada tabel berikut.

Tabel 6. Hasi; Uji Homogenitas Data Pretest Kelompok Eksperimen dan Kelompok Kontrol

Test of Homogeneity of Variances

Minatbelajar1

\begin{tabular}{|c|c|c|c|}
\hline Levene Statistic & df1 & df2 & Sig. \\
\hline 7.350 & 1 & 62 & .009 \\
\hline
\end{tabular}

Berdasarkan hasil analisis tersebut dapat diketahui bahwa hasil uji homogenitas pada kelompok eksperimen dan kelompok kontrol saat pretest dengan nilai signifikansi sebesar 0,009 . Nilai signifikansi tersebut menunjukkan $>0,001$, sehingga dapat dikatakan bahwa data dari kelompok eksperimen dan kelompok kontrol pada saat pretest adalah homogen. Lebih lanjut uji homogenitas juga dilakukan pada data posttest. Berikut merupakan hasil dari uji homogenitas data posttest kelompok eksperimen dan kelompok control.

Tabel 7. Hasi; Uji Homogenitas Data Posttest Kelompok Eksperimen dan Kelompok Kontrol

Test of Homogeneity of Variances

MinatBelajar

\begin{tabular}{|c|c|c|c|}
\hline Levene Statistic & df1 & df2 & Sig. \\
\hline 6.992 & 1 & 62 & .010 \\
\hline
\end{tabular}


Berdasarkan hasil analisis tersebut dapat diketahui bahwa hasil uji homogenitas pada kelompok eksperimen dan kelompok kontrol saat posttest dengan nilai signifikansi yaitu sebesar 0,010. Nilai signifikansi tersebut menunjukkan $>0,001$, sehingga dapat dikatakan bahwa data dari kelompok eksperimen maupun kelompok kontrol pada saat posttest adalah homogen.

\section{c. Hasil Uji T}

Uji T yang digunakan sebagai menganalisis hasil uji coba pada penelitian dan pengembangan ini sudah dapat dilanjutkan pengujiannya karena data sudah dapat dikatakan normal dan homogen. Penentuan ada atau tidaknya perbedaan yang signifikan antar kelompok menggunakan kriteria keputusan. Pallant (2007: p.287) menyatakan bahwa kriteria keputusannya apabila nilai signifikansi $<0,05$, maka dapat disimpulkan bahwa terdapat perbedaan yang signifikan antar kelompok. Berikut merupakan hasil uji $t$ yang dapat dilihat pada tabel berikut.

Tabel 8. Hasil Uji T Data

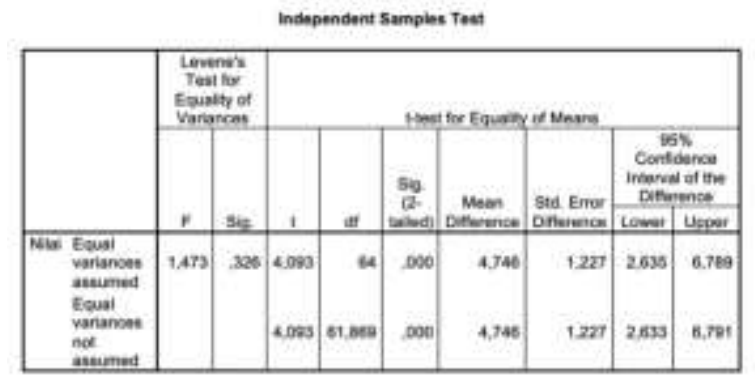

Berdasarkan tabel tersebut dapat diketahui bahwa nilai signifikansi pada tabel Independent Sample Test adalah sebesar 0,000. Nilai tersebut menunjukkan bahwa nilai < 0,05, sehingga dapat disimpulkan bahwa Ho ditolak dan Ha diterima. Sehingga hal tersebut menunjukkan bahwa ada perbedaan yang signifikan antara minat belajar mahasiswa yang diberikan suplemen video pembelajaran dan yang tidak diberikan suplemen video pembelajaran (kelompok eksperimen dan kelompok konrol).

\section{SIMPULAN}

Berdasarkan hasil penelitian dan pengembangan yang sudah diuraikan pada bab sebelumnya menunjukkan bahwa:

1. Kelayakan media pembelajaran berbasis video content youtube berdasarkan penilaian ahli media mencapai skor 5,64 dengan kriteria "Sangat Baik";

2. Penilaian produk oleh 2 (dua) orang dosen pada uji alfa memiliki skor rata-rata sebesar 4,78 dengan kriteria "Sangat Baik";

3. Peningkatan minat belajar mahasiswa sebesar 4,89. Nilai signifikansi sebesar 0,000 yang menunjukkan bahwa terdapat perbedaan yang signifikan antara nilai rata-rata pada pretest dan posttest.

Sehingga dalam hal ini, penggunaan media pembelajaran berbasis video content youtube dapat meningkatkan minat belajr mahasiswa pada mata kuliah sejarah musik 1 . 


\section{REKOMENDASI}

Dalam penyelesaian penelitian dan pengembangan media pembelajaran masih banyak terdapat kekurangan. Sehingga rekomendasi yang dapat diberikan adalah diharapkan kepada peneliti berikutnya dapat memperbaiki bagian-bagian uji coba dalam skala lebih luas, sehingga hasil penelitian yang didapatkan dapat lebih digeneralisasikan.

\section{UCAPAN TERIMAKASIH}

Ucapan terimakasih diberikan kepada Fakultas Bahasa dan Seni, Universitas Negeri Jakarta yang dengan sepenuhnya memberikan bantuan keuangan selama pelaksanaan penelitian berlangsung yang berjudul "Pengembangan Media Pembelajaran Berbasis Video Content Youtube Pada Mata Kuliah Sejarah Musik 1 Materi Perkembangan Musik Kuno di Program Studi Pendidikan Musik UNJ".

Ucapan terimakasih yang tak terhingga diucapkan kepada seluruh mahamahasiswa mata kuliah Sejarah Musik 1 Semester 113 Program Studi Pendidikan Musik, dan seluruh pihak-pihak yang terlibat secara langsung maupun tidak langsung dalam penelitian ini.

\section{DAFTAR PUSTAKA}

Arikunto, S. (2007). Dasar-Dasar Evaluasi Pendidikan. Jakarta: PT Bumi Aksara.

Borg, W.R \& Gall, M.D. (1983). Educational Research: An Introduction, Fourth Edition. New York: Longman Inc.

Handayani, I., Febriyanto, E., \& Kristanti, C. Y. (2019). Komunikasi Dalam Pembelajaran Ilearning Plus Di. 16(2).

Haris Budiman, (2017). Peran Teknologi Informasi dan Komunikasi dalam Pendidikan. AlTadzkiyyah: Jurnal Pendidikan Islam, Vol. 8, Mei 2017, 76.

Johnson, R.A., \& Wichern, D.W. (2007). Applied multivariate statistical analysis. Upper Saddle River: Pearson Education, Inc

Kusnayat, A., Sumarni, N., Mansyur, A. S., Zaqiah, Q. Y., \& Bandung, U. T. (2020). Pengaruh Teknologi Pembelajaran Kuliah Online Di Era Covid-19 Dan Dampaknya Terhadap Mental Mahasiswa. EduTeach : Jurnal Edukasi Dan Teknologi Pembelajaran, 1(2), 153-165.

Pallant, J. (2007). SPSS survival manual. New York: McGraw Hill Open University Press.

Rasagama, I. G. (2020). Pengembangan Model Pembelajaran Getaran Berbasis Video Youtube Untuk Meningkatkan Pemahaman Konsep Mahasiswa Politeknik. Jurnal Pendidikan Sains (Jps), 8(2), 91. https://doi.org/10.26714/jps.8.2.2020.91-101

Rifa'i, M. (2018). Pengembangan Media Pembelajaran Kalkulus Berbasis Web Moodle Pada Mahasiswa STKIP Qomaruddin Gresik. APOTEMA: Jurnal Program Studi Pendidikan ..., 4(2), 27-32. http://194.59.165.171/index.php/APM/article/download/291/203

Simanjuntak, D. (2013). Peranan Teknologi Informasi dan Komunikasi dalam Kurikulum 2013. Jurnal Pendidikan Penabur. Vol.12, 21.

Teni Nurrita. (2018). Pengembangan Media Pembelajaran untuk Meningkatkan Hasil Belajar Siswa. Misykat, vol. 3, No.1, 173.

Yana, D., \& Adam, A. (2019). Efektivitas Penggunaan Platform Lms Sebagai Media Pembelajaran Berbasis Blended Learning Terhadap Hasil Belajar Mahasiswa. Jurnal Dimensi, 8(1), 1-12. https://doi.org/10.33373/dms.v8i1.1816 